\title{
EFL Teachers' Challenges to Write Content and Language Objectives for CBI Lesson Plans at a Mexican University
}

Desafíos de los docentes de EFL al escribir objetivos de contenido

$y$ del idioma para planes de clases de CBI en una universidad mexicana

Desafios dos professores de EFL na redação de objetivos de conteúdo e idioma para os planos de aula do CBI em uma universidade mexicana

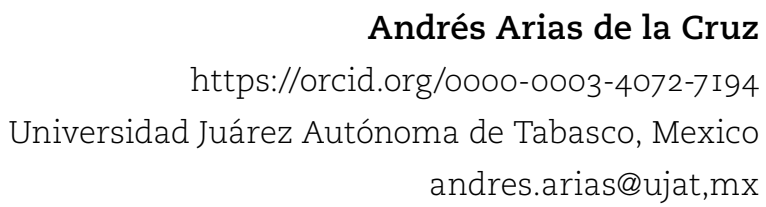

andres.arias@ujat,mx

Received: 23/07/2019

Accepted by peers: 12/02/2020
Sent to peer review: $23 / 01 / 2020$

Approved: 28/02/2020

DOI: 10.5294/laclil.2020.13.2.4

To reference this article (APA) / Para citar este artículo (APA) / Para citar este artigo (APA) Arias, A. (2020). EFL teachers' challenges to write content and language objectives for CBI lesson plans at a Mexican university. Latin American Journal of Content \& Language Integrated Learning, 13(2), 215-240. https://doi.org/10.5294/laclil.2020.13.2.4 
ABSTRACT. This study aims at documenting the challenges that three Mexican students participating in a Content-Based Instruction (CBI) module from a Master's (MA) program in English Language Teaching (ELT) face when writing content and language objectives for CBI lessons. Through qualitative research based on a content analysis design, one lesson plan of each MA student $(n=3)$ was analyzed using criteria proposed by well-known researchers. Results revealed that MA students wrote clear content objectives. The major challenge of content objectives was found in the observability of these objectives. Language objectives were less successful, as most of them were rated as not clear. Moreover, language objectives focused almost exclusively on language skills and grammar and language structures. Finally, the verbs used in the language objectives demanded a low-order cognitive category from students. Despite being EFL trained teachers, these MA students had more challenges in writing language objectives than content objectives. Thus, material, examples, and directions provided to students should explicitly draw students' attention to the most common challenges to help overcome them.

Keywords (Source: Unesco Thesaurus): instruction; teaching guides; objectives; language features; cognitive categories.

RESUMEN. Este estudio tiene como objetivo documentar los desafíos que enfrentaron tres estudiantes mexicanos que participaron en un módulo de instrucción basada en el contenido (IBC) de un programa de maestría en la enseñanza del idioma inglés (EII) al escribir objetivos enfocados en el contenido y objetivos enfocados en el idioma para clases de IBC. A través de una investigación cualitativa basada en un diseño de análisis de contenido, se analizó un plan de clase de cada estudiante de maestría $(n=3)$ utilizando los criterios propuestos por investigadores reconocidos. Los resultados revelaron que los estudiantes de maestría escribieron objetivos de contenido claros. El principal desafío de los objetivos de contenido se encontró en la observabilidad de estos objetivos. Los objetivos enfocados en el idioma fueron menos exitosos, ya que la mayoría de ellos fueron calificados como no claros. Además, los objetivos enfocados en el idioma se centraron casi exclusivamente en las habilidades del lenguaje, la gramática y las estructuras del idioma. Finalmente, los verbos utilizados en los objetivos enfocados en el idioma exigían a los estudiantes una categoría cognitiva de bajo orden. A pesar de ser profesores capacitados en inglés como lengua extranjera, estos estudiantes de maestría tuvieron más desafíos para escribir objetivos enfocados en el lenguaje que en los objetivos de contenido. Por lo tanto, el material, los ejemplos y las instrucciones proporcionadas a los estudiantes deben dirigir explícitamente la atención de los estudiantes hacia los desafíos más comunes para ayudar a superarlos.

Palabras clave (Fuente: tesauro de la Unesco): instrucción; plan de clase; objetivos; aspectos del idioma; categorías cognitivas.

RESUMO. Este estudo tem como objetivo documentar os desafios enfrentados por três estudantes mexicanos que participaram de um módulo de instrução baseada em conteúdo (IBC) de um programa de mestrado em ensino da língua inglesa (IBD), na redação de objetivos focados em conteúdo e metas focadas no idioma para as aulas de IBC. Através de uma pesquisa qualitativa, com base no desenho da análise de conteúdo, analisou-se um plano de aula de cada aluno de mestrado (n = 3), utilizando os critérios propostos por pesquisadores conhecidos. Os resultados revelaram que os alunos do mestrado escreveram objetivos de conteúdo claros. O principal desafio dos objetivos de conteúdo foi encontrado na observabilidade desses objetivos. Os objetivos focados no idioma tiveram menos sucesso, pois a maioria deles foi classificada como não clara. Além disso, os objetivos focados no idioma se concentraram quase exclusivamente nas habilidades linguísticas, a gramática e as estruturas do idioma. Finalmente, os verbos usados em objetivos focados na linguagem exigiam que os alunos tivessem uma categoria cognitiva de ordem inferior. Apesar de serem professores treinados em inglês como língua estrangeira, esses alunos de mestrado tiveram mais desafios em escrever objetivos focados na linguagem do que nos objetivos de conteúdo. Portanto, o material, os exemplos e as instruções fornecidas aos alunos devem direcionar explicitamente a atenção dos alunos para os desafios mais comuns para ajudar a superá-los.

Palavras-chave (Fonte: tesauro da Unesco): instrução; plano de aula; objetivos; aspectos da linguagem; categorias cognitivas. 


\section{Introduction}

In trying to understand what Content-Based Instruction (CBI) means, most researchers (Corrales \& Maloof, 2009; Schleppegrell et al., 2004; Brinton et al., 2003; Burger \& Chretien, 2001) agree that CBI is a combination of disciplinary content and language learning. In other words, CBI means "the integration of particular content with language teaching aims" (Brinton et al., 2003, p. 2). Lyster (2007) states that subject matter provides plenty of opportunities for students to process the language they are studying through content.

However, by definition, CBI aims at integrating both content and language. It has not happened like the vast array of research attests (Arias et al., 2019; Arias \& Izquierdo, 2015; Banegas, 2015; Costa, 2012; Rodgers, 2015; Cammarata \& Tedick, 2012; Zyzik \& Polio, 2008). This lack of integration has been pointed out as one of the main sources of students' language problems (Airey, 2012; Burger \& Chrétien, 2001; Costa, 2012; Lyster, 2007; Rodgers, 2015; Zyzik \& Polio, 2008).

Dalton-Puffer (2008) summarizes these language problems as follows, "students' syntax, writing, informal and non-technical language, pronunciation and pragmatics remain either unaffected or indefinite" (p. 143). Currently, it is accepted that a combination of content and language must be attained in CBI lessons to help students improve their inaccuracies of the target language (Short, 2017; Nikula et al., \& Lorenzo, 2016; Spada et al., \& Valeo, 2014; Cammarata \& Tedick, 2012; Lightbown, 2007; Bigelow et al., 2006;).

CBI has spread to many countries and contexts. Mexico is not an exception. Many universities have bachelor (BA) and MA programs in which CBI is implemented. At the MA level, to date, there are $31 \mathrm{MA}$ programs in English Language Teaching (ELT), 15 offered by public universities and 16 by private universities. They aim to enable in-service teachers to become Masters in English Language Teaching (MELT) [Asociación Nacional de Universidades e Instituciones de Educación Superior (ANUIES), 2017-2018]. Due to institutional necessities, universities appoint some of their teachers to teach content lessons either at the BA or the MA levels. Therefore, some MAs include modules in which teachers are trained to teach CBI lessons. 
There is no research carried out at the MA level documenting how these Mexican MA students are being trained to implement CBI courses. To the best of our knowledge, there are no studies conducted to uncover the challenges these students face when writing both content and language objectives for CBI lessons. Thus, this study aims at finding out the major challenges that three Mexican MA students face when writing content and language objectives for CBI lessons. Outcomes will help the university's authorities, MA staff and teachers to make improvements on the MA program and the CBI module in which this study took place.

\section{Review of the literature}

\section{Integration in CBI}

In the field of education, integration is defined as "the act or process of forming, coordinating, or blending into a functioning or unified whole" (Collins \& O'Brien 2003, p. 183). However, in the field of CBI, it seems that the phrase "content and language integration" may lead us to think about language and content as separate entities (Nikula et al., 2016, p. 2). CBI, by definition, implies that both content and language are integrated. This integration, according to Nikula et al. (2016), needs to occur at different perspectives: the curriculum and pedagogy planning, the participants' perspectives, and the classroom practices.

To integrate language into a CBI course, teachers need to:

Start with content units (integers in maths or track and field sports in PE), represent them in discourse events (describing an ecosystem or comparing warfare strategies) and further split them into language units of different calibre (genres, functions/notions, vocabulary, sentence-grammar units, etc.). (Nikula et al., 2016, p. 14)

For the desired integration of content and language to happen, these aspects must be considered and included in a lesson: content, discourse events, and language units. Yet, this is something already known for teachers, administrators, and stakeholders immersed in CBI contexts; it goes far beyond a simplistic way of teaching a foreign language-a true integration of subject and language learning is sought (Sepešiová, 2015). 
Nonetheless, content and language integration is easier said than done, as results of research coming from different contexts evidence a lack of integration of both content and language. Even more, the vast amount of research evidences an overwhelming emphasis of content over language in many contexts where CBI has been implemented. Creese (2010) claims that, in mainstream classrooms, content knowledge continues to predominate significantly over language.

\section{Challenges that $\mathrm{CBI}$ teachers face to integrate content and language at the lessons planning stage}

Many factors affect the design of a CBI lesson, including factors concerning the learning goals, content and language selection, teaching and learning methods, teaching and learning experiences, material selection, and adaptation, just to mention a few. For instance, the literature reports that teachers usually find it difficult to have access to textbooks and material that proactively integrate both content and language; since most of the material used in these courses is not produced with a language teaching purpose in mind (Brinton et al., 2003, p. 89). In this section, the focus is on those particular challenges directly related to the teachers at the moment of planning content and language lessons.

\section{Lack of integration of content and language as a shortcoming source at the planning stage}

Currently, there is little evidence about what CBI teachers focus on at the time of planning a lesson that aims to integrate both content and language. In his study of 47 unqualified Argentinian teachers who attended an online course to be licensed as English teachers, Banegas (2015) concluded that, even though teachers knew the roles they play as teachers of English and the importance of language in CLIL lessons, they still focused on content.

Similarly, in her quasi experimental study of 58 middle schools and high school teachers in Northern New Jersey, United States, Short (2017) concluded that the experience of working with math and science teachers showed her that, when teachers planned their lessons, they did not think about helping their students develop academic language. 
Even more, although teachers made use of academic discourse, they were not prepared to explicitly teach it to their students.

Echevarria et al., (2010) claim that it is imperative that teachers plan lessons that positively influence students' learning of the target language and that include content and material appropriate for the age of students they are working with.

The overwhelming evidence coming from empirical research indicates that there is not a true integration of both content and language in CBI courses (Arias et al., 2019; Lindseth, 2016; Arias \& Izquierdo, 2015; Airey, 2012; Costa, 2012; Marzban \& Mokhberi, 2012; Unterberger, 2012; Lyster, 2007; Lyster \& Mori, 2006; Zyzik \& Polio, 2008; Loewen, 2005; Swain, 1996).

\section{Major challenges in writing content and language objectives}

If we accept that CBI will soon normalize in many classrooms around the globe, then, we should also accept that there is still some room for improvement in it. Empirical evidence from research indicates that, when trying to integrate content and language in a lesson, teachers face several constraints. "Many times, content and language goals, however, may seem competitive, rather than complementary, with "teachers coming to the conclusion that there is no time to teach language and content because each follows a parallel track" (Bigelow, as cited in Baecher et al., 2014, p. 121).

Moreover, setting clear content and language objectives represents a major challenge in CBI; concerning this, in their investigation of practicum teachers at the final stage of a Master's Program in Teaching English to Speakers of Other Languages (TESOL), Baecher et al. (2014) reported that $55 \%$ of the content objectives were clear and only $38 \%$ of the language objectives were rated as so. Echevarría et al. (2010) concluded that content and language objectives represent a serious challenge for many schoolteachers.

Furthermore, in his study of Argentinian trainee teachers' lesson plans, Banegas (2015) uncovered another challenge; when planning a focus on language, teachers tended to concentrate almost exclusively on language skills: listening (20.34), reading (22.03), speaking (20.34), writing (18.07), and vocabulary (19.21). 
Baecher et al. (2014) reported similar findings as to the lesson plans they analyzed, commonly focused on reading, writing, listening and speaking; the second most common focus was vocabulary (Baecher et al., 2014, p. 131). Additionally, Banegas also reported that, in reference to learning skills, lesson plans usually included "lower-order thinking skills such as remembering" (p. 124).

Costa (2012) arrived at similar findings in her observations of Italian lecturers. She found that there was a greater focus on lexical forms than on any other language feature. Arias and Izquierdo (2015) and Arias et al. (2019) arrived at a similar finding: Mexican teachers focused mainly on lexical features when they paid attention to language.

Seeing content and language as complementary, setting clear content and language objectives, and focusing on more language features rather than relying solely on language skills and vocabulary represent ample windows of opportunity in CBI. In reference to this, teachers play a vital role in making it come true.

Based on the backdrop presented in this literature review, the research questions guiding this study are the following:

1. What are the major challenges for MA in ELT students in writing content objectives at a southeastern Mexican university?

2. What are the major challenges for MA in ELT students in writing language objectives at a southeastern Mexican university?

3. What language categories do the lesson plans written by MA in ELT students focus on?

4. Are language objectives embedded in content area lesson plans promoting low-order or high-order cognitive processes?

\section{Method}

To answer the research questions, the researcher employed a qualitative method to analyze the content and language objectives included in three lesson plans of three MA students participating in a CBI module. As for the research design, it took the form of content analysis.

To comply with the framework proposed by Krippendorff (2004), the study followed these steps: first, the unitizing step; in this case, the units were the content and language objectives of the three lesson 
plans under analysis. Although the next step in the framework is the sampling, for this study, the sampling step did not take place, as there were only three lesson plans available.

Therefore, we moved on to the coding step. Here, the researcher followed the criteria proposed by Echevarría et al. (2010) and Baecher et al. (2014). Once the researcher finished coding, the following steps took place:

- The reducing step, in which the data was reduced using tabulation, presented in the results section;

- The inferring step, in which the content and language objectives were under scrutiny, intending to uncover the challenges MA students face when writing them for CBI lessons; and

- The narrative step, in which the answers to the research questions were provided.

\section{The MA program}

This study took place at a Southeastern Mexican university. The online MA program, from which the CBI training course is under study, was created in 2008 with the main objective of providing teachers of English who already hold a BA in ELT an option to pursue postgraduate studies. The MA in ELT has the objective of training participants to develop the necessary competences to influence positively the process of teaching and learning of the English language (Universidad Juárez Autónoma de Tabasco, 2007). The MA program lasts four semesters.

\section{The $\mathrm{CBI}$ course}

The CBI course analyzed in this study is an online elective course taken in the last semester out of four of the MA program. It aims at helping in-service teachers of English to develop a critical mind on the benefits and limitations of CBI. It also aims at promoting FL development, particularly among adult language learners (Universidad Juárez Autónoma de Tabasco, 2007).

\section{Participants}

Participants for the study were three young Mexican Spanish speaking MA students (one woman and two men). Their names have been 
changed to ensure confidentiality (Ana, Benjamin, and Carlos). They were enrolled in the summer 2016 and 2017 online CBI course of the MA program. All the participants hold a BA in Modern Languages and were in-service teachers teaching English to young learners. They had only received training as EFL teachers.

At the time of the study, the participant MA students were teaching for a 15-week semester at high school and university levels. As it was an online course, instructors and course participants hardly ever saw each other. They got to know each other at a face-to-face session that took place at the very beginning of the module. Therefore, tutorial sessions were held through emails, chats, and videoconferences. As for assignments, students submitted them via email.

\section{Material}

The material comprised one lesson plan from each MA student taking part in this study. The lesson plans did not follow a standard template. Students were free to choose the template. The only requisite to this respect was to choose one suggested in the reading material of the CBI course given to them at the beginning of the module.

In the end, one from each MA student was analyzed. One plan out of three was for high school level, and two for a BA in modern languages. In terms of content, two plans were for geography and culture content, and one was for literature.

\section{Procedure}

The content and language objectives of the three lesson plans were analyzed. To have a clear-cut understanding of what constitutes clear content and language objectives, we adopted the criteria proposed by Echevarría et al. (2010) and Baecher et al. (2014). These criteria served as a guideline in deciding which content and language objectives included in the lesson plans under study were clear.

In this research, clear content objectives possess the following characteristics:

- The [content] objective specifies the content area (e.g., science, social studies, ELA, math) understanding that students will achieve by the end of the lesson; 
- The content objectives are somehow observable. In other words, you will be able to see or recognize when students have accomplished a given task;

- The content objectives are written in a language that students can understand;

- The content objectives are related to the key concept of the lesson; (Echevarría et al., 2010 \& Baecher et al., 2014)

In the same vein, clear language objectives possess the following characteristics:

- The objective specifies the language knowledge, specific to the language learner, and the ability to use it that students will achieve by the end of the lesson.

- The language objective promotes student academic language growth. It is not something most students already do well.

- The language objective connects clearly with the lesson topic or lesson activities (Echevarría et al., 2010; Baecher et al., 2014).

Apart from this, about the language objectives, the research examined the language categories the MA participants used when focusing on language in the lesson plans. These six categories were observed:

- Key vocabulary

- Language functions

- Language skills

- Grammar or language structures

- Lesson task

- Language learning strategies (Echevarría et al., 2010)

Moreover, the verbs used in the content and language objectives were also observed. For this purpose, the categories proposed by Anderson et al. (2001) were useful:

- Remember

- Understand

- Apply

- Analyze

- Evaluate

- Create 


\section{Results}

Ana and Benjamin's lesson plans' area or subject was about geography and culture. Carlos' was about literature. There were two content objectives and two language objectives in Ana's lesson plan. Three content and seven language objectives in Benjamin's. Carlo's lesson plan had two content and two language objectives.

\section{Characteristics of MA students' content objectives}

As for Ana, Benjamin and Carlos' content objectives, Table 1 shows their characteristics.

Table 1. Characteristics of content objectives

\begin{tabular}{|c|c|c|c|c|c|c|c|c|c|c|c|c|c|c|}
\hline \multirow{3}{*}{$\begin{array}{c}\text { Characteristics } \\
\text { of content } \\
\text { objectives }\end{array}$} & \multicolumn{4}{|c|}{ Ana } & \multicolumn{6}{|c|}{ Benjamin } & \multicolumn{4}{|c|}{ Carlos } \\
\hline & \multicolumn{2}{|c|}{ Obj. 1} & \multicolumn{2}{|c|}{ Obj. 2} & \multicolumn{2}{|c|}{ Obj. 1} & \multicolumn{2}{|c|}{ Obj. 2} & \multicolumn{2}{|c|}{ Obj. 3} & \multicolumn{2}{|c|}{ Obj. 1} & \multicolumn{2}{|c|}{ Obj. 2} \\
\hline & Yes & No & Yes & No & Yes & No & Yes & No & Yes & No & Yes & No & Yes & No \\
\hline $\begin{array}{l}\text { The [content] } \\
\text { objective } \\
\text { specifies the } \\
\text { content area } \\
\text { (e.g., science, } \\
\text { social studies, } \\
\text { ELA, math) } \\
\text { understanding } \\
\text { that students } \\
\text { will achieve } \\
\text { by the end } \\
\text { of the lesson } \\
\text { (Baecher et } \\
\text { al., 2014, p. } \\
\text { 126). }\end{array}$ & & $x$ & & $X$ & & $x$ & & $x$ & & $x$ & & & $x$ & \\
\hline
\end{tabular}




\begin{tabular}{|c|c|c|c|c|c|c|c|c|c|c|c|c|c|c|}
\hline \multirow{3}{*}{$\begin{array}{c}\text { Characteristics } \\
\text { of content } \\
\text { objectives }\end{array}$} & \multicolumn{4}{|c|}{ Ana } & \multicolumn{6}{|c|}{ Benjamin } & \multicolumn{4}{|c|}{ Carlos } \\
\hline & \multicolumn{2}{|c|}{ Obj. 1} & \multicolumn{2}{|c|}{ Obj. 2} & \multicolumn{2}{|c|}{ Obj. 1} & \multicolumn{2}{|c|}{ Obj. 2} & \multicolumn{2}{|c|}{ Obj. 3} & \multicolumn{2}{|c|}{ Obj. 1} & \multicolumn{2}{|c|}{ Obj. 2} \\
\hline & Yes & No & Yes & No & Yes & No & Yes & No & Yes & No & Yes & No & Yes & No \\
\hline $\begin{array}{l}\text { The content } \\
\text { objectives } \\
\text { are somehow } \\
\text { observable. In } \\
\text { other words, } \\
\text { you will be } \\
\text { able to see } \\
\text { or recognize } \\
\text { when } \\
\text { students have } \\
\text { accomplished } \\
\text { a given task } \\
\text { (Echevarría et } \\
\text { al., 2010, p. } \\
\text { 34). }\end{array}$ & & & $X$ & & $x$ & & $x$ & & $x$ & & $x$ & & $x$ & $x$ \\
\hline $\begin{array}{l}\text { The content } \\
\text { objectives are } \\
\text { written in a } \\
\text { language that } \\
\text { students can } \\
\text { understand } \\
\text { (Echevarría } \\
\text { et al. 2010, p. } \\
\text { 34). }\end{array}$ & $x$ & & $x$ & & $x$ & & $x$ & & $x$ & & $x$ & & $x$ & \\
\hline $\begin{array}{l}\text { The content } \\
\text { objectives are } \\
\text { related to the } \\
\text { key concept } \\
\text { of the lesson } \\
\text { (Echevarría et } \\
\text { al., 2010, p. } \\
\text { 34). }\end{array}$ & $x$ & & $x$ & & $x$ & & $x$ & & $x$ & & $x$ & & $x$ & \\
\hline
\end{tabular}

Source: Own elaboration.

Regarding the first characteristic in Table 1 , six out of seven content objectives under analysis were rated as clear, since they specify the content area understanding that the students will achieve at the end of the lesson. To illustrate this, a pair of these objectives are inserted below. 
Ana's content objective one:

To identify the differences between British Isles, Great Britain and the United Kingdom.

Benjamin's content objective two:

To tease out who has been the longest reigning monarch in the UK.

Conversely, Carlos' content objective one resulted vague, as the following illustrates:

Learners will be able to demonstrate their previous knowledge about genre, type of literature, and style of writing to sort books according to the existing methods of book classification.

About the second characteristic, none of the content objectives was rated as clear. Given that the objectives were not somehow observable when students had accomplished them.

If we take, for example, Ana's objective one inserted above: "To identify the differences between British Isles, Great Britain and the United Kingdo," here, the wording of the objective did not permit the teacher to realize the moment in which the students have achieved this objective, or the way students have to identify the differences: orally, through a sentence written in their notebooks, through coloring on a map, or how?

As for characteristic three, six out of seven of the objectives were rated as clear. The words used in Ana and Benjamin's content objectives were vocabulary that does not represent a problem for students enrolled in the seventh semester of a BA. To show this, Benjamin's objective number three is as follows:

To recognize current political, social and cultural aspects of the British culture.

Carlos' content objective two is inserted below.

Learners will be able to develop a request of new books for the institutional library budget considering the most relevant books for them.

As Table 1 shows, only one content objective was rated as not clear. In reference to this objective, the way Carlos worded it might represent a challenge for students. The vocabulary he used (e.g., "request" 
and "budget") might not be familiar to students of a third year of high school (the equivalent of tenth graders in the United States education system).

Finally, all the participants' objectives were rated as clear in the last characteristic. All of them were related to the key concept of the lesson. In other words, the content objectives were related to geography and culture in the case of Ana and Benjamin's lessons; and literature in the case of Carlos'.

To illustrate the case, Ana's content objective two is as follows:

To explore geographical differences in the countries which integrate the United Kingdom.

Needless to say, this objective is related to geography, which is the key concept in Ana's lesson.

The following section presents the findings of the language objectives.

\section{Characteristics of MA students' language objectives}

Table 2 below displays the 3 characteristics of the language objectives written by the MA students who participated in this study.

Table 2. Characteristics of language objectives

\begin{tabular}{|c|c|c|}
\hline \multicolumn{3}{|c|}{ Characteristics of language objectives } \\
\hline 1 & 2 & 3 \\
\hline $\begin{array}{l}\text { The objective } \\
\text { specifies the } \\
\text { language } \\
\text { knowledge, } \\
\text { specific to the L2 } \\
\text { learner, and the } \\
\text { ability to use it } \\
\text { that students will } \\
\text { achieve by the } \\
\text { end of the lesson } \\
\text { (Baecher et al., } \\
\text { 2014, p. 126). }\end{array}$ & $\begin{array}{l}\text { The language } \\
\text { objective promotes } \\
\text { student academic } \\
\text { language growth. } \\
\text { It is not something } \\
\text { most students } \\
\text { already do well } \\
\text { (Echevarría et al., } \\
2010, \text { p. 34). }\end{array}$ & $\begin{array}{l}\text { The language } \\
\text { objective connects } \\
\text { clearly with the } \\
\text { lesson topic or } \\
\text { lesson activities } \\
\text { (Echevarría et al., } \\
2010, \text { p. 34). }\end{array}$ \\
\hline
\end{tabular}




\begin{tabular}{|c|c|c|c|c|c|c|}
\hline & Yes & No & Yes & No & Yes & No \\
\hline \multicolumn{7}{|c|}{ Ana's Lesson } \\
\hline Objective 1 & & $x$ & & $x$ & & $x$ \\
\hline Objective 2 & & $x$ & & $x$ & & $X$ \\
\hline \multicolumn{7}{|c|}{ Benjamin's Lesson } \\
\hline Objective 1 & & $x$ & & $x$ & & $x$ \\
\hline Objective 2 & & $x$ & & $x$ & & $x$ \\
\hline Objective 3 & & $x$ & $x$ & & & $x$ \\
\hline Objective 4 & & $x$ & $x$ & & & $x$ \\
\hline Objective 5 & & $x$ & $x$ & & & $x$ \\
\hline Objective 6 & & $x$ & & $x$ & $x$ & \\
\hline Objective 7 & & $x$ & $x$ & & & $x$ \\
\hline \multicolumn{7}{|c|}{ Carlos' Lesson } \\
\hline Objective 1 & & $x$ & $x$ & & & $x$ \\
\hline Objective 2 & & $x$ & & $x$ & & $x$ \\
\hline
\end{tabular}

Source: Own elaboration.

Considering characteristic one in Table 2 above, none of the eleven language objectives complied with the first characteristic. This means that none of them was rated as clear. All the objectives complied with the first part of the characteristic. The objective specifies the language knowledge, the learner needs to focus on. Nonetheless, the second part of this characteristic was problematic for the teachers. These objectives did not specify the ability to use it that students will achieve by the end of the lesson.

As a point in the case, Ana's objective two is inserted:

To use comparatives to describe differences and similarities between two elements.

As read in the objective, the language knowledge was clear; it was about comparatives. This means that the objective complies with the first part of the characteristic. Nevertheless, the objective did not specify the ability to use this knowledge that the students will achieve at the end of the lesson. In other words, it was not stated how students provide evidence that they were able to use that language knowledge at the end of the class. Additionally, the phrase "between two elements" gives a sense of vagueness to this objective. 
See another example from Benjamin:

Reading for specific information and for details.

This objective complies with the first part of the characteristic; it is clear that language knowledge in this objective is a language skill: 230 reading. However, again, the second part of the characteristic is not discernible.

Six language objectives did not comply with the second characteristic. The language objectives did not promote students' academic language growth due to two main reasons:

- The use of basic language structures; and

- The objectives are too general to be able to discern the language feature students are dealing with in the lessons.

This is attested by the following examples:

To be able to use connectors of contrast [subordinate conjunctions] to express differences between two elements.

Ana's objective two above contains a basic language feature. It might mean the objective is not promoting students' language growth.

Students will be also capable of using modal verbs in the context of polite requests.

Carlos' objective two above, as can be seen, is too general.

Listening for specific information.

Likewise, the way Benjamin's objective two is written makes it too general. It is not possible to know the language feature students were dealing with in the lesson.

Similarly, Benjamin's objective six did not provide a clear idea of what vocabulary the students were working with during the lesson:

Vocabulary: geographical, historical, political, social and cultural issues of British culture.

The last criterion of the language objectives considers to what extent the objective connects clearly with the topic or activities of a lesson. Concerning this aspect, ten out of eleven objectives did not comply with this characteristic. In their written form, one cannot connect the objectives with the topics or activities of a lesson. See the following: 
To be able to use connectors of contrast to express differences between two elements.

Here, Ana stated that the topic in her lesson plans was "Geographical features of the British Isles and political differences of the countries in the United Kingdom". Thus, nowhere in the objective was there a direct or even an indirect reference to the topic of the lesson.

Benjamin's objective, on the other hand, was:

Reading: Reading for specific information and for details.

In the case of his lesson, the topic was "UK geographical, historical, political, social and cultural issues." Hence, the way he wrote the language objective shows a disconnection with the topic of the lesson.

The next section deals with the language categories embedded in the language objectives.

\section{Language categories the MA students used when focusing on language in their lesson plans}

Table 3 below presents the results of the language categories found in the language objectives analyzed in this study.

Table 3. Language categories promoted in the language objectives

\begin{tabular}{|l|c|c|c|c|c|c|}
\hline & $\begin{array}{c}\text { Key } \\
\text { vocabulary }\end{array}$ & $\begin{array}{c}\text { Language } \\
\text { functions }\end{array}$ & $\begin{array}{c}\text { Language } \\
\text { skills }\end{array}$ & $\begin{array}{c}\text { Grammar or } \\
\text { language } \\
\text { structures }\end{array}$ & $\begin{array}{c}\text { Lesson } \\
\text { task }\end{array}$ & $\begin{array}{c}\text { Language } \\
\text { learning } \\
\text { strategies }\end{array}$ \\
\hline Ana's Lesson \\
\hline Objective 1 & & $\mathrm{X}$ & & & & \\
\hline Objective 2 & & & $\mathrm{X}$ & & \\
\hline \multicolumn{7}{|l|}{ Benjamin's Lesson } \\
\hline Objective 1 & & $\mathrm{X}$ & & & \\
\hline Objective 2 & & & $\mathrm{X}$ & & & \\
\hline Objective 3 & & & $\mathrm{X}$ & & & \\
\hline Objective 4 & & & $\mathrm{X}$ & & & \\
\hline Objective 5 & & & & $\mathrm{X}$ & & \\
\hline Objective 6 & $\mathrm{X}$ & & & & & \\
\hline Objective 7 & & $\mathrm{X}$ & & & & \\
\hline
\end{tabular}




\begin{tabular}{|l|c|c|c|c|c|c|}
\hline & $\begin{array}{c}\text { Key } \\
\text { vocabulary }\end{array}$ & $\begin{array}{l}\text { Language } \\
\text { functions }\end{array}$ & $\begin{array}{c}\text { Language } \\
\text { skills }\end{array}$ & $\begin{array}{c}\text { Grammar or } \\
\text { language } \\
\text { structures }\end{array}$ & $\begin{array}{c}\text { Lesson } \\
\text { task }\end{array}$ & $\begin{array}{c}\text { Language } \\
\text { learning } \\
\text { strategies }\end{array}$ \\
\hline Carlos' Lesson \\
\hline Objective 1 & & & $\mathrm{X}$ & & \\
\hline Objective 2 & & & $\mathrm{X}$ & & \\
\hline
\end{tabular}

Source: Own elaboration.

As can be observed in Table 3, the language objectives focused mainly on two categories: grammar or language structures and language skills with four objectives for each category. Two language objectives focused on the language and function category and only one objective on key vocabulary.

\section{Verbs used in the language objectives}

Considering the verbs used in the language objectives, Table 4 shows the preferred verbs used in the lesson plans.

Table 4. Verbs used in the language objectives

\begin{tabular}{|c|c|c|c|c|c|c|}
\hline & Remember & Understand & Apply & Analyze & Evaluate & Create \\
\hline \multicolumn{7}{|c|}{ Ana's Lesson } \\
\hline Objective 1 & & & $x$ & & & \\
\hline Objective 2 & & & $x$ & & & \\
\hline \multicolumn{7}{|c|}{ Benjamin's Lesson } \\
\hline Objective 1 & & $x$ & & & & \\
\hline Objective 2 & & $x$ & & & & \\
\hline Objective 3 & & & $x$ & & & \\
\hline Objective 4 & & $x$ & & & & \\
\hline Objective 5 & \multicolumn{6}{|c|}{ No verb was used in this objective } \\
\hline Objective 6 & \multicolumn{6}{|c|}{ No verb was used in this objective } \\
\hline Objective 7 & & & & & $x$ & \\
\hline \multicolumn{7}{|c|}{ Carlos' Lesson } \\
\hline Objective 1 & $x$ & & & & & \\
\hline Objective 2 & & & $x$ & & & \\
\hline
\end{tabular}

Source: Own elaboration. 
One out of nine language objectives focused on the most basic cognitive process is "remembering." Three concentrated on the "understanding" category, and four concentrated on the "applying" category. Just one demanded evaluation from students. Thus, most language objectives demanded a low-order cognitive process from students: understanding and applying.

\section{Discussion}

In reference to the first question of this study (i.e., "What are the major challenges for MA in ELT students in writing content objectives at a Southeastern Mexican university?"), This is not what was stated in the abstract. One of the ourcomes of the study is precisely the opposite to what is presented here. Elaborate on this. The vocabulary used to write the objectives was easy to understand by students, and all of them were related to the key concept of the lesson. This finding is parallel to that of Baecher et al. (2014), as in their study, 55\% of the content objectives was rated as clear.

Why do you claim it was suprising that the content objectives were clear? This is a really surprising finding, as the MA students in this study were EFL trained teachers. This means they were trained to teach language and, therefore, one can expect they have more problems in writing content objectives. This finding may be attributed to the material they read, and the examples provided in the material they received at the beginning of the CBI module. Moreover, the transferring of this information to their own planning is something to highlight. Thus, a careful selection of material and a flood of examples are vital if we want students to have a clear-cut understanding of how to write clear content objectives.

The only drawback found was that the objectives were written in a way that a teacher cannot realize when the students have achieved them. This may have occurred due to the students' lack of information about how specific these objectives needed to be. Thus, it seems necessary to explicitly train the CBI module's participants on how specific content objectives need to be. 
Question two asked about the major challenges for MA in ELT students in writing language objectives. Here, most of the objectives were rated as "not clear." They did not specify how students will provide evidence that they were able to use that language knowledge at the end of the class. Moreover, they did not promote academic language growth due to the use of basic language structures. Furthermore, the objectives did not connect clearly with the topics or activities of the lesson.

This may have happened due to the lack of training in writing and integrating both content and language in a CBI course (Airey, 2012; Costa, 2012). Or because nowhere in the course syllabus it is established that teachers needed to promote or integrate language (Arias \& Izquierdo, 2015). Or maybe because the university evaluations of these CBI courses focus on content and not on language (Unterberger, 2012).

Furthermore, the participants might have thought that content was more important than language. Thus, they concentrated their efforts on writing content objectives (Arias et al., 2019; Costa, 2012; Banegas, 2015). It may also be plausible that information about language objectives and the objectives provided as models in the material of the module were not clear or explicit enough to this respect.

This is a quite interesting finding, given that the participants are language teachers. Therefore, one can expect that they write clear language objectives. Nonetheless, one thing is writing language objectives for a language lesson and a very different thing is writing them for a CBI one, not to mention the complexity that comes into play when an integration of both content and language objectives is sought. This is a huge and complex task for CBI teachers. Thus, this is where they need more training. Train teachers on integrating objectives, since the very planning stage of a lesson will help overcome many of the language problems commonly reported in CBI.

Question three asked about the language categories the lesson plans focus on. Four out of eleven language objectives focused on language skills: listening, reading, writing, and speaking; and another four focused on grammar or language structures. This finding of language skills is similar to that reported by Baecher et al. (2014) and Banegas (2015).

Commonly, in empirical research, vocabulary is the most or the second most common language feature teachers (Costa, 2012) and lesson plans (Baecher et al., 2014; Banegas, 2015) focus on. Nonetheless, 
in this study, grammar or language structures were the second most common language features.

Participants may have focused mainly on the language skills because "it is common for ESL instruction to focus on reading and writing and other skill areas" (Baecher et al. 2014, p. 132). Moreover, the focus on grammar or language structures may be explained as one area of language, particularly that those trained as EFL teachers would be most likely to focus on. Also, because these EFL teachers may associate the idea of teaching language to the teaching of grammar or language structures.

A surprising finding was that vocabulary was relegated to the last place, just after language and functions. The reading material provided in the module may have played a significant role; in it, there was an emphasis on the teaching of vocabulary as the most common language feature CBI teachers tend to focus on. In other words, the reading material provided to students considers the teaching of lexis (almost exclusively) as a weakness in CBI.

This emphasis on teaching vocabulary as a weakness in CBI may have influenced these MA students' decision at the time of selecting which language features to focus on. At least at the level of planning, it contradicts what has been found in another empirical research.

However, one thing is what is planned, and a different thing is what happens when implementing a lesson. It may be interesting to find out if what was written in these lesson plans really took place at the time of implementation.

Question four inquired whether language objectives embedded in content area lesson plans promoted low-order or high-order cognitive processes. Most language objectives demanded low-order thinking skills, mostly "understanding" and "applying. This finding is similar to the one by Banegas (2015).

We need to accept that this is an area that teachers tend to neglect. One cannot expect teachers to pay attention to low- and high-order thinking skills when writing language objectives if they have not received training on it or they have not been explicitly asked about it; or they have not been made aware of the importance of these skills and how they aid or hinder students' learning process. Thus, it is important to train, explicitly ask, and make teachers reflect on the importance of writing objectives that demand high-order thinking skills from their pupils. 


\section{Conclusion}

Our findings suggest that crafting both content and language objectives is vital for CBI teachers, at least for the context where this study took place. Evidence shows that major challenges of language objectives relate to lack of clarity in them, few language features attended to, and low-order cognitive processes. Writing clear content and language objectives does not happen by osmosis.

The disconnection found between the language objectives and the topic or subject of the lessons shows that these lessons are far from integrating content and language objectives. The fact that a lesson plan contains both types of objectives does not mean they are truly integrated.

Therefore, the claim is that CBI teachers need to write not only clear but also integrated content and language objectives. Fulfilling the content and language objective sections of a lesson plan does not necessarily mean integration.

Consequently, students participating in our MA program need training on:

1. What aspects need to be taken into consideration to write clear language objectives.

2. How to write clear and integrated language objectives that focus on the different language features.

3. How to write language objectives that promote the different cognitive processes rather than focusing on just the low-order cognitive ones.

4. What criteria a language objective must comply with.

Pertaining to the limitations of this study, the first one relates to the number of lesson plans analyzed. Only three lesson plans is a very small number, thus, making it very difficult to generalize the results to all the MA students participating in this program. Future research needs to consider a larger number of lesson plans.

Second, results were based just on three lesson plans. It may be interesting to hear the voices of the MA students to know their reasons for the way they crafted both content and language objectives. 


\section{References}

Airey, J. (2012). "I don't teach language": The linguistic attitudes of physics lectures in Sweden. AILA Review, 25(2012), 64-79. https://doi. org/10.1075/aila.25.05air

Anderson, L., Krathwohl, D., Airasian, P., Cruikshank, K., Mayer, R., Pintrich, P., Raths, J., \& Wittrock, M. (Eds.). (2001). A taxonomy for learning, teaching, and assessing: A revision of Bloom's taxonomy of educational objectives. Addison Wesley Longman, Inc.

Arias, A., \& Izquierdo, J. (2015). Language attention in content-based instruction: The case of language instructors teaching content in a foreign language in Mexican higher education. Journal of Immersion and Content-Based Language Education, 3(2), 194-217. http://doi. org/10.1075/jicb.3.2.02ari

Arias, A., Domínguez, G., \& Morales, E. (2019). Form-focused instruction (FFI) and language features attended to during content-based instruction (CBI) lessons at a southeastern Mexican university. Actualidades Investigativas en Educación, 19(1),1-28. https://doi.org/10.15517/ aie.v19i1.34785

Arnó-Macià, E., \& Mancho-Barés, G. (2015). The role of content and language in content and language integrated learning (CLIL) at university: Challenges and implications for ESP. English for Specific Purposes, 37(2015), 63-73. https://doi.org/10.1016/j.esp.2014.06.007

Asociación Nacional de Universidades e Instituciones de Educación Superior (ANUIES). (2017-2018). Catálogo de carreras de licenciatura y posgrado. https://www.anuies.mx/iinformacion-y-servicios/informacion-estadistica-de-educacion-superior/anuario-estadistico-de-educacion-superior

Baecher, L., Farnsworth, T., \& Ediger, A. (2014). The challenges of planning language objectives in content-based ESL instruction. LanguageTeaching Research,18(I), 118-136. https://doi.org/10.1177/1362168813505381

Banegas, D. L. (2015). Sharing views of CLIL lesson planning in language teacher education. Latin American Journal of Content and Language Integrated Learning, 8(2), 104-130. https://doi.org/10.5294/lacli1.2015.8.2.3

Bigelow, M., Ranney, S., \& Dahlman, A. (2006). Keeping the language focus in content-based ESL instruction through proactive curriculum 
planning. TESL Canada Journal, 24(1), 40-58. https://doi.org/10.18806/ tesl.v24i1.27

Brinton, D., Snow, M., \& Wesche, M. (2003). Content-based second language instruction. The University of Michigan Press.

Burger, S., \& Chrétien, M. (2001). The development of oral production in content-based second language courses at the university of Ottawa. The Canadian Modern Language Review, 58(1), 84-102. https://doi. org/10.3138/cmlr.58.1.84

Cammarata, L., \& Tedick, D. (2012). Balancing content and language in instruction: The experience of immersion teachers. Modern Language Journal, 96(ii), 251-269. https://doi.org/10.1111/j.15404781.2012.01330.x

Collins, J. W., \& O'Brien, N. P. (2003). The Greenwood dictionary of education. Greenwood publishing group.

Corrales, K., \& Maloof, C. (2009). Evaluating the effects of CBI on an English for medical students program. Latin American Journal of Content \& Language Integrated Learning, 2(1), 15-23. https://doi.org/10.5294/ laclil.2009.2.1.3

Costa, F. (2012). Focus on form in ICLHE lectures in Italy. AILA Review, 25(2012), 30-47. https://doi.org/10.1075/aila.25.03cos

Creese, A. (2010). Content focused classrooms and learning English: How teachers collaborate. Theory into practice, 49, 99-105. https://doi. org/10.1080/00405841003626494

Dalton-Puffer, C. (2008). Outcomes and processes in content and language integrated learning (CLIL): Current research from Europe. In W. Delanoy \& I. Volkmann (Eds.), Future perspectives for English language teaching. Anglistische Forschunge (Vol. 388, pp. 139-157). Winter.

Echevarria, J., Vogt, M., \& Short, D. J. (2010). Making content comprehensible for secondary English learners the SIOP model. Pearson Education.

Ellis, R., Basturkmen, H., \& Loewen, S. (2002). Doing focus-on-form. System, 30(2002), 419-432. https://doi.org/10.1016/S0346-251X(02)00047-7

Krippendorff, K. (2004). Content analysis: An introduction to its methodology. Sage Publications.

Lara, R., Richter, G., Razo, L. O., \& Gonzalez, L. D. (2016). Mexican teachers' perceptions of teaching English through content-based instruction in the state of Guanajuato Mexico: A dual perspective. Entreciencias: 
diálogos en la sociedad del conocimiento, 4(9), 97-108. http://www.redalyc.org/articulo.oa?id=457645340008

Lightbown, P. M. (2007). Fair trade: Two-way bilingual education. Estudios de Lingüística Inglesa Aplicada, 7, 9-34. http://revistas.uned.es/index. php/ELIA/article/view/18087/

Lindseth, M. (2016). The effects of form-focused instruction on the acquisition of subject-verb inversion in German. Foreign Language Annals, 49(1), 10-22. https://doi.org/10.1111/flan.12174

Loewen, S. (2005). Incidental focus on form and second language learning. SSLA, 27, 361-386. https://doi.org/10.1017/S0272263105050163

Lyster, R., \& Ballinger, S. (2011). Content-based language teaching: Convergent concerns across divergent contexts. Language Teaching Research, 15(3), 279-288. https://doi.org/10.1177/1362168811401150

Lyster, R., \& Mori, H. (2006). Interactional feedback and instructional counterbalance. Studies in Second Language Acquisition, 28, 269-300. https:// doi.org/10.1017/S0272263106060128

Lyster, R. (2007). Learning and teaching languages through content: A counterbalanced approach. John Benjamins.

Marzban, A., \& Mokhberi, M. (2012). The effect of focus on form instruction on intermediate EFL learners' grammar learning in task-based language teaching. Procedia - Social and Behavioral Sciences, 46(2012), 5340-5344. https://doi.org/10.1016/j.sbspro.2012.06.435

Nikula, T., Dalton-Puffer, C., Llinates, A., \& Lorenzo, F. (2016). More than content and language: The complexity of integration in CLIL and multilingual education. In Nikula, T., Dafouz, E., Moore, P. \& Smit, U. (Ed.). Conceptualising integration in CLIL and multilingual education (pp. 1-25). Multilingual matters.

Rodgers, D. (2015). Incidental language learning in foreign language content courses. The Modern Language Journal, 99(1), 113-136. https://doi. org/10.1111/modl.12194

Schleppegrell, M., Achugar, M., \& Orteíza, T. (2004). The grammar of history: Enhancing content-based instruction through a functional focus on language. TESOL Quarterly, 38(1), 67-93. https://doi. org $/ 10.2307 / 3588259$

Sepešiová, M. (2015). CLIL lesson planning. In Pokrivcákǒvá et al. (Ed.), CLIL in foreign language education: E-textbook for foreign language teachers (pp. 131-152). https://doi.org/10.17846/CLIL.2015.131-152 
Short, D. J. (2017). How to integrate content and language learning effectively for English language learning. EURASIA Journal of Mathematics Science and Technology Education, 13(7b), 4237-4260. https://doi. org/10.12973/eurasia.2017.00806a

Spada, N., Jessop, L., Tomita, Y., Suzuki, W., \& Valeo, A. (2014). Isolated and integrated form-focused instruction: Effects on different types of L2 knowledge. Language Teaching Research, 18(4), 453-473. https:// doi.org/10.1177/1362168813519883

Swain, M. (1996). Integrating language and content in immersion classrooms: Research perspectives. The Canadian Modern Language Review, 52, 529-548. https://doi.org/10.3138/cmlr.52.4.529

Universidad Juárez Autónoma de Tabasco. (2007). Plan de estudios de la maestría en la enseñanza del idioma inglés. Villahermosa, Mexico.

Unterberger, B. (2012). English-medium programmes at Austrian business faculty. A status quo survey on national trends and a case study on programme design and delivery. AlLA Review, 25(2012), 80-100. https://doi.org/10.1075/aila.25.06unt

Zyzik, E. \& Polio, C. (2008). Incidental focus on form in university Spanish literature courses. The Modern Language Journal, 92(i), 53-70. https:// doi.org/10.1111/j.1540-4781.2008.00686.x 